\title{
Time trends of physical inactivity in Brazilian adults from 2009 to 2017
}

\author{
Michael Pereira da Silva1* (1), Fabio Fontana ${ }^{2}$ (D), Jhonathan Gritten Campos $^{3}$ (1), \\ Oldemar Mazzardo $\mathbb{1}^{\mathbb{D}}$, Dartel Ferrari Lima ${ }^{4} \mathbb{1}$, Ana Carolina Paludo 5 (1), \\ Wagner de Campos $^{3}$
}

\section{SUMMARY}

OBJECTIVE: The aim was to evaluate the changes in the prevalence of physical inactivity in the Brazilian adults from 2009-2017. METHODS: This study used a time-series research design based on the cross-sectional data of 462,498 Brazilian adults from $2009-2017$. Participants were classified as physically inactive if they indicated not participating in physical activity in the last three months. The PraisWinsten regression analyzed physical inactivity trends over time.

RESULTS: The overall prevalence of physical inactivity was stable ( $p>0.05)$. Physical inactivity increased for women in four state capitals (annual growth rate: Goiânia 1.62\%, Campo Grande 3.28\%, Porto Velho 0.93\%, and Vitória 2.09\%) and decreased in one (annual growth rate: Rio Branco 4.50\%). Physical inactivity decreased for men in four state capitals (annual growth rate: Campo Grande $4.72 \%$, Natal $2.73 \%$, São Luís 4.94\%, and Rio Branco 2.95\%).

CONCLUSION: The physical inactivity among the Brazilian adults was stable between 2009 and 2017. Physical inactivity increased in women from Goiânia, Campo Grande, Porto Velho, and Vitória and decreased in women from Rio Branco and in men from Campo Grande, Natal, São Luís, and Rio Branco.

KEYWORDS: Sedentary behavior. Population surveillance. Epidemiology.

\section{INTRODUCTION}

Physical inactivity is the fourth leading cause of deaths worldwide $^{1}$, accounting for $6-10 \%$ of all deaths ${ }^{2}$. Considering that $27.5 \%$ of the world population performs an insufficient amount of physical activity $(\mathrm{PA})^{3}$, physical inactivity is a major modern time threat to public health. For substantial health benefits, adults should engage in at least $150 \mathrm{~min}$ of moderate-intensity PA or 75 min of vigorous-intensity PA weekly ${ }^{4,5}$.

Surveillance of PA informs public health authorities and assists in evaluating research efforts and policies aimed at increasing population levels of $\mathrm{PA}^{3}$. Some countries have implemented
PA surveillance systems, including the United States, Canada, Germany, France, and others ${ }^{6}$. In Brazil, the Ministry of Health has implemented a health surveillance system called VIGITEL ${ }^{7}$. This system provides annual information on PA behavior for 26 states and the Federal District of Brazil. VIGITEL describes the prevalence of physical inactivity based on adults reporting a lack of engagement in PA during leisure time, at work, at home, or commuting to work or school ${ }^{7}$.

Previous investigations have examined the time trends of PA patterns based on VIGITEL data ${ }^{8-12}$. However, the lack of estimates of physical inactivity trends $s^{8,9}$, the selection of a subsample of adults with health insurance ${ }^{12}$, and the use of a

\footnotetext{
'Universidade Federal do Rio Grande, Faculty of Medicine, Physical Activity and Public Health Research Group - Rio Grande (RS), Brazil. ${ }^{2}$ University of Northern lowa, Department of Kinesiology and Physical Education - lowa, United States of America.

${ }^{3}$ Universidade Federal do Paraná, Department of Physical Education - Curitiba (PR), Brazil.

${ }^{4}$ Universidade Estadual do Oeste do Paraná, Department of Physical Education, - Marechal Cândido Rondon (PR), Brazil.

${ }^{5}$ Universidade Estadual do Centro Oeste, Department of Physical Education, - Guarapuava (PR), Brazil.

*Corresponding author: prof.mpsilva@outlook.com

Conflicts of interest: the authors declare there are no conflicts of interest. Funding: none.

Received on February 07, 2021. Accepted on February 08, 2021.
} 
time-series statistical analysis which failed to account for serial autocorrelations ${ }^{10,11}$ may limit the ability of previous studies to evaluate physical inactivity trends in the Brazilian adults. Additionally, the data on regional time trends of physical inactivity are scarce in Brazil. Therefore, this study aimed to evaluate the overall and state-capital-specific changes in the prevalence of physical inactivity in the Brazilian adults from 2009-2017.

\section{METHODS}

\section{Study design}

This study used a time-series design based on the cross-sectional data collected by VIGITEL from 2009-2017 in all 26 state capitals and the Federal District of Brazil. The detailed methodological procedures can be found elsewhere? ${ }^{7}$. The VIGITEL project was approved by the National Commission on Ethics in Research Involving Human Participants (Protocol no ${ }^{\circ} .355,590$ ). All participants provided informed consent form at the beginning of the telephone interviews.

\section{Sample}

The VIGITEL collected the data based on probabilistic samples of the Brazilian adults ( $\geq 18$ years old) living in households with at least one fixed telephone line across all state capitals and the Federal District of Brazil and used the rake method to calculate post-stratification sample weights for each city ${ }^{13}$. From 2009-2017, VIGITEL conducted 462,498 interviews of adults of both sexes (Table 1).

\section{Physical inactivity}

The physical inactivity indicator refers to people who reported neither participating in PA during their free time in the last three months, partaking in intense physical exertion at work, actively commuting to work or school by walking or biking for at least $10 \mathrm{~min}$, nor performing intense household cleaning $^{7,11}$. The VIGITEL questionnaire has adequate validity (area under the receiver operating characteristic curve: $\mathrm{AUC}=0.75$ ) and reliability $(\text { kappa }=0.70)^{14}$.

\section{Data analysis}

The Prais-Winsten regression models analyzed the time trends of physical inactivity. This procedure allows the correction of serial autocorrelations when analyzing values organized over time ${ }^{15,16}$. The prevalence rates were calculated using sample weights, log transformed, and used as dependent variables, while each year of observation was used as an independent variable. We assumed

Table 1. Total interviews conducted in state capitals and Federal District of Brazil from 2009-2017.

\begin{tabular}{|c|c|c|c|c|c|c|c|c|c|c|}
\hline & $\begin{array}{c}2009 \\
(n=54,367)\end{array}$ & $\begin{array}{c}2010 \\
(n=54,339)\end{array}$ & $\begin{array}{c}2011 \\
(n=52,144)\end{array}$ & $\begin{array}{c}2012 \\
(n=45,448)\end{array}$ & $\begin{array}{c}2013 \\
(n=52,929)\end{array}$ & $\begin{array}{c}2014 \\
(n=40,853)\end{array}$ & $\begin{array}{c}2015 \\
(n=54,174)\end{array}$ & $\begin{array}{c}2016 \\
(n=53,210)\end{array}$ & $\begin{array}{c}2017 \\
(n=53,034)\end{array}$ & $\begin{array}{c}\text { Total } \\
(n=462,498)\end{array}$ \\
\hline & $\begin{array}{c}n \\
(\%)\end{array}$ & $\begin{array}{c}n \\
(\%)\end{array}$ & $\begin{array}{c}n \\
(\%)\end{array}$ & $\begin{array}{c}n \\
(\%)\end{array}$ & $\begin{array}{c}n \\
(\%)\end{array}$ & $\begin{array}{c}n \\
(\%)\end{array}$ & $\begin{array}{c}n \\
(\%)\end{array}$ & $\begin{array}{c}n \\
(\%)\end{array}$ & $\begin{array}{c}n \\
(\%)\end{array}$ & $\begin{array}{c}n \\
(\%)\end{array}$ \\
\hline \multicolumn{11}{|l|}{ Sex } \\
\hline Men & $\begin{array}{l}21,347 \\
(39.26)\end{array}$ & $\begin{array}{l}20,764 \\
(38.21)\end{array}$ & $\begin{array}{l}20,641 \\
(39.60)\end{array}$ & $\begin{array}{l}17,389 \\
(38.26)\end{array}$ & $\begin{array}{l}20,276 \\
(38.31)\end{array}$ & $\begin{array}{l}15,521 \\
(37.99)\end{array}$ & $\begin{array}{l}20,368 \\
(31.60)\end{array}$ & $\begin{array}{l}20,258 \\
(38.07)\end{array}$ & $\begin{array}{l}19,504 \\
(37.78)\end{array}$ & $\begin{array}{c}176,068 \\
(38.23)\end{array}$ \\
\hline Women & $\begin{array}{l}33,020 \\
(60.74)\end{array}$ & $\begin{array}{l}33,575 \\
(61.79)\end{array}$ & $\begin{array}{l}31,503 \\
(60.41)\end{array}$ & $\begin{array}{c}28,059 \\
(61.74 \%)\end{array}$ & $\begin{array}{l}32,653 \\
(61.69)\end{array}$ & $\begin{array}{l}25,332 \\
(62.01)\end{array}$ & $\begin{array}{l}33,806 \\
(62.40)\end{array}$ & $\begin{array}{l}32,952 \\
(61.93)\end{array}$ & $\begin{array}{l}33,530 \\
(63.22)\end{array}$ & $\begin{array}{c}284,430 \\
(61.77)\end{array}$ \\
\hline \multicolumn{11}{|c|}{ Age (years) } \\
\hline $18-24$ & $\begin{array}{c}7,760 \\
(14.27)\end{array}$ & $\begin{array}{c}7,364 \\
(13.55)\end{array}$ & $\begin{array}{c}6,971 \\
(12.87)\end{array}$ & $\begin{array}{c}5,353 \\
(11.78)\end{array}$ & $\begin{array}{c}4,316 \\
(11.02)\end{array}$ & $\begin{array}{c}4,316 \\
(10.56)\end{array}$ & $\begin{array}{l}5,050 \\
(9.32)\end{array}$ & $\begin{array}{l}5,163 \\
(9.70)\end{array}$ & $\begin{array}{l}4,510 \\
(8.50)\end{array}$ & $\begin{array}{l}52,321 \\
(11.31)\end{array}$ \\
\hline $25-34$ & $\begin{array}{l}10,664 \\
(15.59)\end{array}$ & $\begin{array}{l}10,573 \\
(19.46)\end{array}$ & $\begin{array}{l}10,147 \\
(18.74)\end{array}$ & $\begin{array}{c}8,020 \\
(17.65)\end{array}$ & $\begin{array}{c}8,253 \\
(19.61)\end{array}$ & $\begin{array}{c}6,307 \\
(15.44)\end{array}$ & $\begin{array}{c}7,163 \\
(13.22)\end{array}$ & $\begin{array}{c}6,945 \\
(13.05)\end{array}$ & $\begin{array}{c}6,000 \\
(11.31)\end{array}$ & $\begin{array}{l}74,072 \\
(16.02)\end{array}$ \\
\hline $35-44$ & $\begin{array}{l}11,369 \\
(20.91)\end{array}$ & $\begin{array}{l}10,902 \\
(20.06)\end{array}$ & $\begin{array}{l}10,436 \\
(19.27)\end{array}$ & $\begin{array}{c}8,580 \\
(18.88)\end{array}$ & $\begin{array}{c}9,069 \\
(17.13)\end{array}$ & $\begin{array}{c}7,054 \\
(17.27)\end{array}$ & $\begin{array}{c}8,463 \\
(15.62)\end{array}$ & $\begin{array}{c}7,925 \\
(14.89)\end{array}$ & $\begin{array}{c}7,416 \\
(13.98)\end{array}$ & $\begin{array}{l}81,214 \\
(17.56)\end{array}$ \\
\hline $45-54$ & $\begin{array}{l}10,238 \\
(18.83)\end{array}$ & $\begin{array}{l}10,271 \\
(18.90)\end{array}$ & $\begin{array}{l}10,359 \\
(19.13)\end{array}$ & $\begin{array}{c}8,723 \\
(19.19)\end{array}$ & $\begin{array}{r}10,004 \\
(18.90) \\
\end{array}$ & $\begin{array}{c}7,656 \\
(18.74) \\
\end{array}$ & $\begin{array}{c}9,750 \\
(18.00)\end{array}$ & $\begin{array}{c}9,374 \\
(17.62)\end{array}$ & $\begin{array}{l}8,937 \\
16.85)\end{array}$ & $\begin{array}{l}85,312 \\
(18.45)\end{array}$ \\
\hline $55-64$ & $\begin{array}{c}7,450 \\
(13.70)\end{array}$ & $\begin{array}{c}7,889 \\
(14.52)\end{array}$ & $\begin{array}{c}8,157 \\
(15.07)\end{array}$ & $\begin{array}{c}7,192 \\
(15.82)\end{array}$ & $\begin{array}{c}9,369 \\
(17.70)\end{array}$ & $\begin{array}{c}7,103 \\
(17.39)\end{array}$ & $\begin{array}{l}10,399 \\
(19.20)\end{array}$ & $\begin{array}{l}10,154 \\
(19.08)\end{array}$ & $\begin{array}{l}10,444 \\
(19.69)\end{array}$ & $\begin{array}{l}78,157 \\
(16.90)\end{array}$ \\
\hline $\begin{array}{l}65 \text { or } \\
\text { above }\end{array}$ & $\begin{array}{c}6,886 \\
(12.67)\end{array}$ & $\begin{array}{c}7,340 \\
(13.51)\end{array}$ & $\begin{array}{c}8,074 \\
(14.91)\end{array}$ & $\begin{array}{c}7,580 \\
(16.68)\end{array}$ & $\begin{array}{r}10,400 \\
(19.65)\end{array}$ & $\begin{array}{c}8,417 \\
(20.60)\end{array}$ & $\begin{array}{l}13,349 \\
(24.64)\end{array}$ & $\begin{array}{l}13,649 \\
(25.65)\end{array}$ & $\begin{array}{l}15,727 \\
(29.65)\end{array}$ & $\begin{array}{l}91,422 \\
(19.77)\end{array}$ \\
\hline
\end{tabular}

Source: VIGITEL. 
significant changes in the prevalence of physical inactivity when the regression coefficients differed from zero $(\mathrm{p}<0.05)$. We calculated annual growth rates and $95 \%$ confidence intervals $(95 \% \mathrm{CI})$ using the following equations ${ }^{16}$ :

Annual growth rate $=-1+10^{b}$

$95 \% \mathrm{CI}=-1+10(b \pm t \times \mathrm{SE})$

Stata MP 14.1 (Stata Corp LLC, College Station, TX, USA) statistical package performed all the analyses.

\section{RESULTS}

\section{Overall changes in physical inactivity}

The prevalence of physical inactivity remained stable from 2009-2017 (Figure 1). In 2017, 13.7\% of the sample reported being physically inactive.

\section{Midwest and northeast regions}

The prevalence of physical inactivity decreased for men living in the cities of Campo Grande (-4.72\%, 95\%CI -8.38- -0.46), Natal $(-2.73 \%, 95 \%$ CI $-5.16-0.46)$, and São Luís $(-4.94 \%$, $95 \% \mathrm{CI}-7.32--2.50)$. The prevalence of physical inactivity increased for women living in Campo Grande $(3.28 \%$, 95\% CI 1.39-5.20) and Goiânia (1.62\%, 95\%CI 0.23-3.28) (Table 2).

\section{North, southeast, and south regions}

The prevalence of physical inactivity decreased for the overall sample of adults living in the cities of Macapá $(-3.39 \%, 95 \%$ CI -6.46$-0.23)$ and Rio Branco $(-4.06 \%, 95 \%$ CI $-5.59-2.50)$ and increased in Curitiba (2.09\%; 95\%CI 0.69-3.28). The prevalence of physical inactivity decreased for men $(-2.95 \%, 95 \% \mathrm{CI}-5.81-0.23)$ and women $(-4.50 \%, 95 \% \mathrm{CI}-7.32--1.60)$ from Rio Branco and for women from Macapá $(-2.28 \%, 95 \%$ CI $-4.50-0.23)$ from 2009 to 2017. The prevalence of physical inactivity increased for women in Porto Velho $(0.93 \%$, 95\%CI 0.23-1.89) and Vitória (2.09\%; 95\%CI 0.69-3.51) (Table 3).

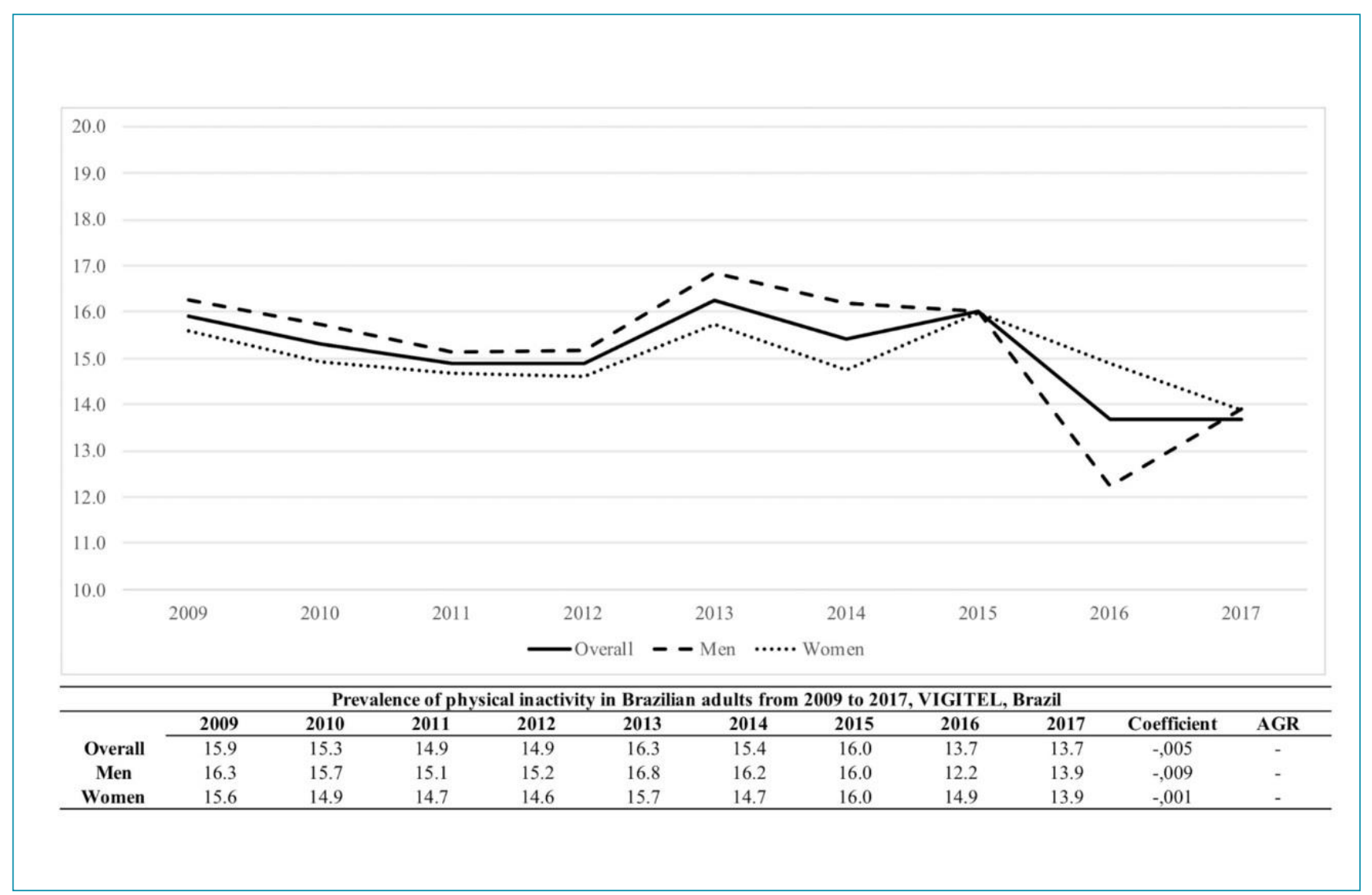

Figure 1. The prevalence of physical inactivity from 2009-2017 in Brazil (Source: VIGITEL, Brazil). 
Table 2. Prevalence, regression coefficients, and annual growth rate for physical inactivity in the Midwest and Northeast regions of Brazil.

\begin{tabular}{|c|c|c|c|c|c|c|c|c|c|c|c|c|}
\hline & 2009 & 2010 & 2011 & 2012 & 2013 & 2014 & 2015 & 2016 & 2017 & Coefficient & $p$ & $\begin{array}{c}\text { AGR } \\
(\%)\end{array}$ \\
\hline \multicolumn{13}{|l|}{ Midwest } \\
\hline \multicolumn{13}{|c|}{ Campo Grande } \\
\hline Overall & 12.30 & 13.90 & 15.70 & 14.00 & 13.90 & 13.00 & 13.80 & 13.30 & 12.70 & -0.002 & 0.62 & - \\
\hline Men & 14.00 & 16.70 & 18.70 & 15.20 & 14.10 & 14.40 & 14.00 & 12.90 & 9.70 & -0.021 & 0.03 & -4.72 \\
\hline Women & 10.70 & 11.30 & 13.10 & 12.80 & 13.70 & 11.80 & 13.70 & 13.80 & 15.50 & 0.014 & 0.004 & 3.28 \\
\hline \multicolumn{13}{|l|}{ Cuiabá } \\
\hline Overall & 15.40 & 14.70 & 14.60 & 13.70 & 16.80 & 13.10 & 12.60 & 13.00 & 15.90 & -0.005 & 0.27 & - \\
\hline Men & 13.50 & 15.40 & 14.70 & 12.90 & 17.50 & 11.70 & 12.40 & 12.80 & 16.50 & -0.004 & 0.22 & - \\
\hline Women & 17.20 & 14.00 & 14.50 & 14.40 & 16.10 & 14.40 & 12.80 & 13.10 & 15.40 & -0.006 & 0.18 & - \\
\hline \multicolumn{13}{|c|}{ Federal District } \\
\hline Overall & 13.20 & 15.80 & 12.20 & 11.90 & 13.10 & 14.00 & 13.90 & 10.30 & 10.70 & -0.012 & 0.09 & - \\
\hline Men & 7.30 & 22.70 & 9.80 & 11.50 & 12.30 & 13.50 & 12.60 & 9.00 & 8.90 & -0.015 & 0.22 & - \\
\hline Women & 18.40 & 9.70 & 14.30 & 12.30 & 13.90 & 14.50 & 15.10 & 11.40 & 12.40 & -0.002 & 0.79 & - \\
\hline \multicolumn{13}{|l|}{ Goiânia } \\
\hline Overall & 13.80 & 12.20 & 12.90 & 12.10 & 14.60 & 13.90 & 17.90 & 11.40 & 13.40 & 0.004 & 0.49 & - \\
\hline Men & 15.20 & 13.60 & 13.10 & 11.40 & 15.90 & 14.50 & 21.50 & 10.60 & 12.90 & 0.000 & 0.99 & - \\
\hline Women & 12.60 & 11.00 & 12.80 & 12.80 & 13.40 & 13.40 & 14.60 & 12.10 & 13.80 & 0.007 & 0.04 & 1.62 \\
\hline \multicolumn{13}{|l|}{ Northeast } \\
\hline \multicolumn{13}{|l|}{ Aracaju } \\
\hline Overall & 19.00 & 17.60 & 18.10 & 15.60 & 19.10 & 18.60 & 15.50 & 18.10 & 18.00 & -0.001 & 0.62 & - \\
\hline Men & 19.70 & 20.20 & 19.70 & 15.80 & 18.40 & 18.90 & 14.90 & 18.80 & 19.90 & -0.004 & 0.43 & - \\
\hline Women & 18.50 & 15.50 & 16.70 & 15.40 & 19.70 & 18.40 & 16.10 & 17.50 & 16.40 & 0.006 & 0.22 & - \\
\hline \multicolumn{13}{|l|}{ Fortaleza } \\
\hline Overall & 14.60 & 15.20 & 14.60 & 16.50 & 19.20 & 17.80 & 17.20 & 15.60 & 16.20 & 0.006 & 0.37 & - \\
\hline Men & 15.30 & 16.40 & 16.30 & 16.60 & 20.10 & 15.10 & 16.70 & 13.00 & 15.60 & 0.003 & 0.72 & - \\
\hline Women & 13.90 & 14.30 & 13.30 & 16.40 & 18.50 & 20.00 & 17.60 & 17.70 & 16.80 & 0.013 & 0.12 & - \\
\hline \multicolumn{13}{|c|}{ João Pessoa } \\
\hline Overall & 17.20 & 18.70 & 17.80 & 16.10 & 21.10 & 19.30 & 20.30 & 17.80 & 17.50 & 0.003 & 0.54 & - \\
\hline Men & 17.70 & 19.50 & 20.80 & 15.80 & 22.40 & 20.20 & 17.90 & 17.70 & 15.70 & -0.005 & 0.31 & - \\
\hline Women & 16.70 & 18.00 & 15.20 & 16.20 & 20.10 & 18.60 & 22.30 & 18.00 & 19.00 & 0.010 & 0.07 & - \\
\hline \multicolumn{13}{|l|}{ Maceio } \\
\hline Overall & 20.30 & 17.80 & 16.70 & 18.20 & 19.90 & 16.80 & 19.40 & 17.00 & 18.40 & -0.001 & 0.62 & - \\
\hline Men & 22.80 & 16.70 & 18.20 & 18.40 & 21.40 & 16.60 & 21.10 & 15.80 & 18.20 & -0.004 & 0.27 & - \\
\hline Women & 18.20 & 18.80 & 15.30 & 17.90 & 18.60 & 17.00 & 18.00 & 18.00 & 18.70 & 0.001 & 0.54 & - \\
\hline \multicolumn{13}{|l|}{ Natal } \\
\hline Overall & 17.50 & 17.70 & 16.20 & 18.20 & 18.10 & 15.50 & 19.50 & 16.60 & 17.70 & 0.000 & 0.84 & - \\
\hline Men & 16.40 & 22.20 & 19.50 & 18.10 & 20.20 & 13.40 & 20.00 & 15.80 & 16.20 & -0.012 & 0.03 & -2.73 \\
\hline Women & 18.50 & 13.90 & 13.50 & 18.30 & 16.20 & 17.20 & 19.10 & 17.20 & 19.00 & 0.011 & 0.06 & - \\
\hline \multicolumn{13}{|l|}{ Recife } \\
\hline Overall & 18.60 & 17.00 & 18.20 & 18.50 & 19.30 & 18.20 & 19.20 & 16.80 & 17.70 & -0.001 & 0.74 & - \\
\hline Men & 15.30 & 15.50 & 18.10 & 21.50 & 17.70 & 17.80 & 18.70 & 13.80 & 17.20 & 0.003 & 0.97 & - \\
\hline Women & 21.20 & 18.10 & 18.20 & 16.00 & 20.60 & 18.60 & 19.50 & 19.20 & 18.00 & 0.000 & 0.96 & - \\
\hline
\end{tabular}


Table 2. Continuation.

\begin{tabular}{|c|c|c|c|c|c|c|c|c|c|c|c|c|}
\hline & 2009 & 2010 & 2011 & 2012 & 2013 & 2014 & 2015 & 2016 & 2017 & Coefficient & $p$ & $\begin{array}{c}\text { AGR } \\
(\%)\end{array}$ \\
\hline \multicolumn{13}{|l|}{ Salvador } \\
\hline Overall & 14.40 & 13.70 & 14.60 & 15.00 & 14.30 & 13.80 & 17.10 & 12.10 & 14.10 & -0.002 & 0.62 & - \\
\hline Men & 12.90 & 12.40 & 13.20 & 15.50 & 15.50 & 13.80 & 16.90 & 9.90 & 15.10 & 0.001 & 0.88 & - \\
\hline Women & 15.70 & 14.80 & 15.70 & 14.60 & 13.30 & 13.70 & 17.10 & 13.90 & 13.20 & -0.005 & 0.26 & - \\
\hline \multicolumn{13}{|l|}{ São Luís } \\
\hline Overall & 18.00 & 16.60 & 15.20 & 13.90 & 19.00 & 13.80 & 18.20 & 15.60 & 13.60 & -0.004 & 0.34 & - \\
\hline Men & 18.40 & 18.20 & 15.90 & 12.90 & 16.70 & 12.60 & 16.40 & 12.10 & 10.80 & -0.022 & 0.002 & -4.94 \\
\hline Women & 17.70 & 15.30 & 14.60 & 14.70 & 20.90 & 14.70 & 19.70 & 18.60 & 15.90 & 0.008 & 0.14 & - \\
\hline \multicolumn{13}{|l|}{ Teresina } \\
\hline Overall & 16.70 & 18.40 & 16.90 & 16.50 & 21.70 & 19.80 & 17.30 & 16.30 & 17.40 & 0.000 & 0.95 & - \\
\hline Men & 15.80 & 19.40 & 18.70 & 14.70 & 24.00 & 19.70 & 15.50 & 14.60 & 17.00 & -0.005 & 0.54 & - \\
\hline Women & 17.50 & 17.60 & 15.50 & 17.90 & 19.80 & 19.90 & 18.70 & 17.70 & 17.60 & 0.002 & 0.60 & - \\
\hline
\end{tabular}

AGR: annual growth rate. Bold values indicate significant changes in the prevalence of physical inactivity $(p<0.05)$.

Table 3. Prevalence, regression coefficients, and annual growth rate for physical inactivity in the North, Southeast, and South regions of Brazil.

\begin{tabular}{|c|c|c|c|c|c|c|c|c|c|c|c|c|}
\hline \multicolumn{13}{|c|}{ Prevalence (\%) } \\
\hline & 2009 & 2010 & 2011 & 2012 & 2013 & 2014 & 2015 & 2016 & 2017 & Coefficient & $p$ & $\begin{array}{c}\text { AGR } \\
(\%)\end{array}$ \\
\hline \multicolumn{13}{|l|}{ North } \\
\hline \multicolumn{13}{|l|}{ Belém } \\
\hline Overall & 14.10 & 15.70 & 13.30 & 15.60 & 16.70 & 17.00 & 14.90 & 14.20 & 14.50 & 0.001 & 0.86 & - \\
\hline Men & 12.20 & 12.20 & 12.40 & 14.10 & 13.80 & 15.20 & 15.10 & 9.90 & 10.90 & -0.004 & 0.65 & - \\
\hline Women & 15.70 & 18.80 & 14.00 & 16.90 & 19.20 & 18.50 & 14.80 & 17.80 & 17.50 & 0.003 & 0.56 & - \\
\hline \multicolumn{13}{|l|}{ Boa Vista } \\
\hline Overall & 15.00 & 16.50 & 11.30 & 14.30 & 16.30 & 15.30 & 14.30 & 12.30 & 14.20 & -0.004 & 0.53 & - \\
\hline Men & 15.30 & 14.40 & 11.70 & 16.00 & 16.80 & 15.40 & 15.00 & 12.30 & 14.00 & -0.002 & 0.72 & - \\
\hline Women & 14.80 & 18.60 & 10.90 & 12.60 & 15.80 & 15.30 & 13.50 & 12.30 & 14.40 & -0.005 & 0.48 & - \\
\hline \multicolumn{13}{|l|}{ Macapá } \\
\hline Overall & 18.30 & 13.50 & 17.90 & 15.20 & 18.40 & 16.20 & 12.80 & 13.80 & 11.90 & -0.015 & 0.04 & -3.39 \\
\hline Men & 18.10 & 9.50 & 18.30 & 15.90 & 17.80 & 14.50 & 9.90 & 12.50 & 9.30 & -0.020 & 0.13 & - \\
\hline Women & 18.60 & 17.30 & 17.60 & 14.50 & 19.00 & 17.70 & 15.60 & 15.00 & 14.40 & -0.010 & 0.04 & -2.28 \\
\hline \multicolumn{13}{|l|}{ Manaus } \\
\hline Overall & 15.50 & 10.70 & 16.20 & 13.80 & 16.00 & 15.50 & 17.10 & 13.50 & 12.30 & 0.002 & 0.75 & - \\
\hline Men & 14.50 & 8.90 & 12.70 & 10.90 & 15.40 & 15.70 & 18.10 & 12.70 & 12.00 & 0.011 & 0.32 & - \\
\hline Women & 16.50 & 12.30 & 19.40 & 16.60 & 16.50 & 15.40 & 16.20 & 14.30 & 12.50 & -0.007 & 0.34 & - \\
\hline \multicolumn{13}{|l|}{ Palmas } \\
\hline Overall & 13.50 & 11.90 & 15.80 & 12.20 & 17.50 & 13.40 & 12.80 & 12.60 & 11.70 & -0.005 & 0.43 & - \\
\hline Men & 13.80 & 8.90 & 11.40 & 14.70 & 19.80 & 15.90 & 13.00 & 10.40 & 11.60 & 0.045 & 0.07 & - \\
\hline Women & 13.30 & 13.60 & 20.20 & 9.90 & 15.30 & 11.10 & 12.60 & 14.60 & 11.80 & -0.008 & 0.23 & - \\
\hline
\end{tabular}


Table 3. Continuation.

\begin{tabular}{|c|c|c|c|c|c|c|c|c|c|c|c|c|}
\hline \multicolumn{13}{|c|}{ Prevalence (\%) } \\
\hline & 2009 & 2010 & 2011 & 2012 & 2013 & 2014 & 2015 & 2016 & 2017 & Coefficient & $p$ & $\begin{array}{c}\text { AGR } \\
(\%)\end{array}$ \\
\hline \multicolumn{13}{|c|}{ Porto Velho } \\
\hline Overall & 12.50 & 13.30 & 12.40 & 12.80 & 16.20 & 11.60 & 15.00 & 12.40 & 13.00 & 0.001 & 0.65 & - \\
\hline Men & 12.60 & 13.60 & 11.00 & 13.30 & 17.80 & 10.30 & 15.40 & 11.30 & 12.70 & -0.001 & 0.85 & - \\
\hline Women & 12.40 & 13.00 & 13.70 & 12.30 & 14.50 & 13.10 & 14.60 & 13.50 & 13.20 & 0.004 & 0.04 & 0.93 \\
\hline \multicolumn{13}{|l|}{ Rio Branco } \\
\hline Overall & 16.20 & 22.10 & 17.50 & 16.40 & 17.70 & 14.60 & 17.40 & 13.10 & 14.40 & -0.018 & $<0.001$ & -4.06 \\
\hline Men & 15.50 & 18.30 & 18.40 & 17.10 & 18.20 & 15.10 & 15.10 & 12.60 & 14.80 & -0.013 & 0.03 & -2.95 \\
\hline Women & 16.90 & 25.60 & 16.70 & 15.80 & 17.30 & 14.20 & 19.40 & 13.50 & 14.10 & -0.020 & 0.001 & -4.50 \\
\hline \multicolumn{13}{|l|}{ Southeast } \\
\hline \multicolumn{13}{|l|}{ Vitória } \\
\hline Overall & 14.80 & 13.20 & 12.90 & 14.20 & 14.30 & 14.40 & 15.70 & 12.30 & 14.90 & 0.002 & 0.57 & - \\
\hline Men & 16.10 & 14.00 & 11.90 & 12.30 & 14.40 & 14.10 & 16.20 & 9.50 & 12.90 & -0.009 & 0.28 & - \\
\hline Women & 13.70 & 12.50 & 13.80 & 15.80 & 14.20 & 14.70 & 15.40 & 14.60 & 16.50 & 0.009 & 0.007 & 2.09 \\
\hline \multicolumn{13}{|c|}{ Belo Horizonte } \\
\hline Overall & 14.90 & 11.90 & 14.40 & 14.60 & 15.30 & 13.10 & 15.60 & 13.20 & 13.50 & 0.001 & 0.78 & \\
\hline Men & 17.50 & 13.30 & 15.90 & 15.40 & 14.90 & 16.60 & 17.50 & 14.50 & 14.10 & -0.001 & 0.83 & \\
\hline Women & 12.70 & 10.70 & 13.20 & 14.00 & 15.70 & 10.20 & 14.00 & 12.20 & 13.00 & 0.002 & 0.71 & \\
\hline \multicolumn{13}{|c|}{ Rio de Janeiro } \\
\hline Overall & 16.10 & 14.80 & 12.50 & 16.60 & 15.90 & 16.50 & 14.40 & 13.80 & 14.50 & -0.002 & 0.66 & - \\
\hline Men & 18.50 & 13.00 & 13.30 & 15.90 & 17.40 & 17.30 & 15.20 & 11.40 & 13.40 & -0.011 & 0.32 & - \\
\hline Women & 14.10 & 16.40 & 11.90 & 17.20 & 14.60 & 15.80 & 13.80 & 15.80 & 15.40 & 0.003 & 0.36 & - \\
\hline \multicolumn{13}{|l|}{ São Paulo } \\
\hline Overall & 16.60 & 13.00 & 13.30 & 14.10 & 16.30 & 15.40 & 16.10 & 13.00 & 12.40 & -0.007 & 0.37 & - \\
\hline Men & 17.60 & 15.50 & 13.50 & 15.80 & 17.90 & 18.50 & 15.70 & 11.50 & 14.30 & -0.009 & 0.35 & - \\
\hline Women & 15.60 & 10.90 & 13.10 & 12.70 & 15.00 & 12.80 & 16.50 & 14.30 & 10.80 & 0.003 & 0.64 & - \\
\hline \multicolumn{13}{|l|}{ South } \\
\hline \multicolumn{13}{|l|}{ Curitiba } \\
\hline Overall & 12.30 & 12.20 & 11.20 & 13.30 & 13.50 & 13.00 & 13.10 & 14.00 & 14.00 & 0.009 & 0.006 & 2.09 \\
\hline Men & 14.80 & 13.70 & 9.90 & 13.40 & 13.10 & 14.20 & 13.20 & 14.50 & 16.40 & 0.009 & 0.24 & - \\
\hline Women & 10.20 & 10.80 & 12.40 & 13.10 & 13.90 & 11.90 & 13.10 & 13.70 & 12.00 & 0.010 & 0.12 & - \\
\hline \multicolumn{13}{|c|}{ Florianópolis } \\
\hline Overall & 11.50 & 12.20 & 10.80 & 11.40 & 13.40 & 13.10 & 12.40 & 11.20 & 13.90 & 0.006 & 0.17 & - \\
\hline Men & 11.30 & 13.30 & 11.40 & 9.50 & 13.00 & 12.90 & 10.60 & 10.00 & 14.00 & -0.001 & 0.24 & - \\
\hline Women & 11.70 & 11.30 & 10.30 & 13.20 & 13.80 & 13.40 & 14.10 & 12.20 & 13.80 & 0.011 & 0.06 & - \\
\hline \multicolumn{13}{|c|}{ Porto Alegre } \\
\hline Overall & 13.30 & 13.10 & 13.60 & 14.50 & 14.00 & 14.50 & 17.60 & 15.20 & 12.70 & 0.005 & 0.40 & - \\
\hline Men & 12.60 & 13.10 & 12.30 & 16.80 & 13.60 & 13.40 & 18.30 & 15.90 & 12.00 & 0.009 & 0.21 & - \\
\hline Women & 13.90 & 13.10 & 14.70 & 12.70 & 14.40 & 15.40 & 17.10 & 14.70 & 13.20 & 0.004 & 0.43 & - \\
\hline
\end{tabular}

AGR: annual growth rate. Bold values indicate significant changes in the prevalence of physical inactivity $(p<0.05)$. 


\section{DISCUSSION}

Physical inactivity is a significant public health problem and an important factor for worldwide mortality ${ }^{2}$. Thus, monitoring of physical inactivity can inform public policies aimed at increasing the population levels of PA. This study assessed the time trends of physical inactivity in Brazil indicating that the prevalence of physical inactivity has remained stable from 20092017. In addition, stratifications indicated different time trends of physical inactivity by sex and state capital. More specifically, we observed an increase in inactivity for women in four state capitals and a decrease for men in four major state capitals.

This study indicated that the prevalence of physical inactivity for the overall sample remained stable from 2009-2017. Our results are similar to the findings of previous investigations. Guthold et al. ${ }^{3}$ found a stable prevalence of physical inactivity worldwide and for Latin and Caribbean countries from 20012016 despite differences in the definition of physical inactivity. While Guthold et al. ${ }^{3}$ defined physical inactivity as an insufficient level of PA to meet the current recommendations advocated by the WHO, we defined physical inactivity as a lack of PA engagement in four domains: leisure, transportation, work, and home ${ }^{7,11}$. Our findings also corroborate the results of previous studies using the VIGITEL data ${ }^{10-12}$. Even after accounting for the dependence of a measure of physical inactivity assessed at multiple time points using adequate time-series data analyses, the stability of prevalence of physical inactivity in the overall sample was similar to previous VIGITEL studies ${ }^{10-12}$. Increasing the participation of fairly sedentary individuals in $\mathrm{PA}$ is a challenge in Brazil.

The adherence to WHO PA recommendations has increased in Brazil since $2006^{8}$. Considering the results of this study and previous VIGITEL studies ${ }^{10-12}$ indicating a stable prevalence of physical inactivity in the past decade, the growth in the adherence to PA recommendations is likely a result of changes in PA engagement of adults who are classified as insufficiently active. Even small increments in the PA habits of those reporting extremely low levels of PA are expected to contribute significantly in order to reduce the risk of early deaths ${ }^{17,18}$. To effectively reduce public health problems associated with physical inactivity, Brazil should focus on increasing the PA levels of the portion of the population who are fairly sedentary.

A closer inspection of our data revealed differences in the time trends by state capital and sex. While 18 Brazilian state capitals had a stable prevalence of physical inactivity for the overall sample, one state capital showed decreased the prevalence of physical inactivity for the overall sample, four state capitals showed decreased the prevalence of physical inactivity for men, and four other state capitals showed increased physical inactivity prevalence for women. To better understand these time trends, it is necessary to reflect on the goals Brazil has outlined for the reduction of chronic noncommunicable diseases including investing on policies to promote PA at the population level ${ }^{19}$. From this perspective, the National Policy for Health Promotion ${ }^{19}$ was established in 2006, ratifying the commitment of Brazilian federal government to expanding public health actions and promoting new PA programs. Furthermore, the Brazilian Ministry of Health funded 748 PA programs in the first year of inception of the National Policy for Health Promotion ${ }^{20}$. Several other large-scale PA public programs were created by the Brazilian Unified Health System in this past decade ${ }^{21}$. These actions mainly reach populations of low socioeconomic status and intend to reduce economic disparities to PA access ${ }^{19,21,22}$.

A recent study demonstrates that only $20 \%$ of the Brazilian adult population is aware of public PA programs, and $1.9 \%$ have ever engaged in one of these programs ${ }^{22}$. However, regional differences in the access PA public programs might help explaining the differences in time trends for each state capital and sex. In our study, the five state capitals decreasing physical inactivity are in regions with more participation in public PA programs such as the North, Northeast, and Midwest regions of Brazil $^{22}$. Therefore, further studies should examine the impact of these programs on the time trends of physical inactivity in Brazilian state capitals.

The results for five Brazilian capitals were alarming (Curitiba, Goiânia, Campo Grande, Porto Velho, and Vitória). Physical inactivity increased in these cities, especially for women. Physical inactivity plays an important role in the alarming rates of obesity observed today, and the increase in this behavior can contribute to the maintenance of these rates in women. Obese women have the higher risk of cardiovascular diseases, diabetes, endometrial and breast cancer, subfertility, and worse obstetric and perinatal outcomes ${ }^{23-25}$. Increasing PA in women might help them manage their weight, especially in women at risk of obesity, and offer additional benefits to women's health.

Worldwide, the prevalence of physical inactivity is $8 \%$ higher in women than in men $^{3,26}$. Brazilian women are more aware of PA public programs, but they engage in these programs to the same extent as men ${ }^{22}$. Identification and removal of barriers for participation of Brazilian women in PA may bridge the gap between awareness and engagement in these programs. Our results suggest reinforcing the need to design targeted policies that facilitate the engagement of Brazilian women in PA programs. Unsafe neighborhoods, lack of social support, and countless responsibilities are common barriers for the engagement of women in PA. Creating safe places for PA and offering support such as child care may encourage women to be more active ${ }^{27}$. 


\section{STRENGTHS AND LIMITATIONS}

This is the first study to show the time trends of the prevalence of physical inactivity for each Brazilian state capital. The VIGITEL estimate of physical inactivity is the strength of this study. It reflects the self-reported measures of nearly absolute lack of engagement in PA in several domains. It is clear that it limits the comparability with other major international studies, but it also offers valuable information regarding people who are fairly physically inactive.

The VIGITEL study limited the interviews to fixed telephone lines. The fixed telephone line is generally associated with sectors of the population with higher schooling and income. Although this procedure could lead to selection bias, we addressed this issue by using sample weights to guarantee the representativeness of the sample ${ }^{28}$. Moreover, a previous study using the VIGITEL survey suggested that excluding cellphone users did not impact the estimates of physical inactivity ${ }^{13}$. The self-reported measures of physical inactivity could be affected by recall and social desirability bias. However, these measures are common in nationwide surveys, and the VIGITEL questionnaire has adequate validity and reliability ${ }^{14}$.

Physical inactivity has remained stable from 2009-2017 for the overall sample, but there were observed differences by region and sex. The overall prevalence of PA decreased in the cities of Macapá and Rio Branco and increased in Curitiba.
For men, the prevalence of physical inactivity decreased in Campo Grande, Natal, São Luís, and Rio Branco. For women, the prevalence of physical inactivity increased in Goiânia, Campo Grande, Porto Velho, and Vitória and decreased in Rio Branco.

\section{ACKNOWLEDGMENTS}

The VIGITEL project was approved by the National Commission of Ethics in Research for Human Beings of the Brazilian Ministry of Health. Free and informed consent was obtained orally at the time of telephone contact with the interviewees. The database is public and available online at http://svs.aids. gov.br/bases_vigitel_viva/vigitel.php, and it does not allow interviewees to be identified.

\section{AUTHORS" CONTRIBUTIONS}

MPS: Conceptualization, Formal Analysis, Writing - Original Draft, Writing - Review \& Editing. FF: Conceptualization, Writing - Original Draft, Writing - Review \& Editing. GC: Conceptualization, Writing - Original Draft, Writing - Review \& Editing. OM: Writing - Original Draft, Writing - Review \& Editing. DFL: Writing - Original Draft, Writing - Review \& Editing. ACP: Writing - Original Draft, Writing - Review \& Editing. WC: Writing - Review \& Editing.

\section{REFERENCES}

1. Kohl HW 3rd, Craig CL, Lambert EV, Inoue S, Alkandari JR, Leetongin $\mathrm{G}$, et al. The pandemic of physical inactivity: global action for public health. Lancet. 2012;380(9838):294-305. https://doi.org/10.1016/\$0140-6736(12)60898-8

2. Lee I-M, Shiroma EJ, Lobelo F, Puska P, Blair SN, Katzmarzyk PT. Effect of physical inactivity on major non-communicable diseases worldwide: an analysis of burden of disease and life expectancy. Lancet. 2012;380(9838):219-29. https://doi. org/10.1016/S0140-6736(12)61031-9

3. Guthold R, Stevens GA, Riley LM, Bull FC. Worldwide trends in insufficient physical activity from 2001 to 2016: a pooled analysis of 358 population-based surveys with 1.9 million participants. Lancet Glob Health. 2018;6(10):e1077-86. https://doi.org/10.1016/S2214-109X(18)30357-7

4. World Health Organization. Guidelines on physical activity and sedentary behaviour for children and adolescents, adults and older adults. Geneva: World Health Organization; 2020. [cited on Dec. 1, 2020]. Available from: https://apps.who.int/ iris/rest/bitstreams/1315866/retrieve

5. U.S. Department of Health and Human Services. Physical activity guidelines for americans. 2nd ed. Washington, DC: U.S. Department of Health and Human Services; 2018.
6. Varela AR, Salvo D, Pratt M, Milton K, Siefken K, Bauman $A$, et al. Worldwide use of the first set of physical activity Country Cards: The Global Observatory for Physical Activity - GoPA! Int J Behav Nutr Phys Act. 2018;15(1):29. https:// doi.org/10.1186/s12966-018-0663-7

7. Moura EC, Morais Neto OL de, Malta DC, et al. Vigilância de Fatores de Risco para Doenças Crônicas por Inquérito Telefônico nas capitais dos 26 estados brasileiros e no Distrito Federal (2006). Rev Bras Epidemiol. 2008;11(Suppl 1):20-37. https://doi.org/10.1590/S1415-790X2008000500003

8. Cruz MS da, Bernal RTI, Claro RM. Tendência da prática de atividade física no lazer entre adultos no Brasil (20062016). Cad Saude Publica. 2018;34(10):1-14. https://doi. org/10.1590/0102-311X00114817

9. Mielke GI, Hallal PC, Malta DC, Lee IM. Time trends of physical activity and television viewing time in Brazil: 2006-2012. Int J Behav Nutr Phys Act. 2014;11:101. https://doi.org/10.1186/ s12966-014-0101-4

10. Hallal PC, Knuth AG, Reis RS, Airton J Rombaldi AJ, Malta DC, Iser BPM, et al. Tendências temporais de atividade física no Brasil (2006-2009). Rev Bras Epidemiol. 2011;14(Suppl 1):5360. https://doi.org/10.1590/S1415-790X2011000500006 
11. Malta D, Andrade S, Santos M, Rodrigues G, Mielke G. Tendências dos indicadores de atividade física em adultos: conjunto de capitais do Brasil 2006-2013. Rev Bras Ativ Fís Saúde. 2015;20(2):141. https://doi.org/10.12820/ rbafs.v.20n2p141

12. Malta DC, Bernal RTI, Vieira Neto E, Curci KA, Pasinato MTM, Lisbôa RM. et al. Tendências de fatores de risco e proteção de doenças crônicas não transmissíveis na população com planos de saúde no Brasil de 2008 a 2015. Rev Bras Epidemiol. 2018;21(Suppl 1):e180020. https://doi.org/10.1590/1980549720180020.supl.1

13. Bernal RTI, Malta DC, Claro RM, Monteiro CA. Effect of the inclusion of mobile phone interviews to Vigitel. Rev Saude Publica. 2017;51(Suppl 1):15s. https://doi.org/10.1590/S15188787.2017051000171

14. Moreira AD, Claro RM, Felisbino-Mendes MS, VelasquezMelendez G. Validity and reliability of a telephone survey of physical activity in Brazil. Rev Bras Epidemiol. 2017;20(1):13646. https://doi.org/10.1590/1980-5497201700010012

15. Antunes JLF, Cardoso MRA. Uso da análise de séries temporais em estudos epidemiológicos. Epidemiol Serv Saúde. 2015;24(3):565-76. https://doi.org/10.5123/S167949742015000300024

16. Biazevic MGH, Castellanos RA, Antunes JLF, Michel-Crosato E. Tendências de mortalidade por câncer de boca e orofaringe no Município de São Paulo, Brasil, 1980/2002. Cad Saude Publica. 2006;22(10):2105-14. https://doi.org/10.1590/s0102$311 \times 2006001000016$

17. Saint-Maurice PF, Troiano RP, Matthews CE, Kraus WE. Moderateto-vigorous physical activity and all-cause mortality: do bouts matter? J Am Heart Assoc. 2018;7(6):e007678. https://doi. org/10.1161/JAHA.117.007678

18. Saint-Maurice PF, Troiano RP, Berrigan D, Kraus WE, Matthews CE. Volume of light versus moderate-to-vigorous physical activity: similar benefits for all-cause mortality? J Am Heart Assoc. 2018;7(7):e008815. https://doi.org/10.1161/ JAHA. 118.008815

19. Malta DC, Barbosa da Silva J. Policies to promote physical activity in Brazil. Lancet. 2012;380(9838):195-6. https://doi. org/10.1016/S0140-6736(12)61041-1
20. Amorim T, Knuth A, Cruz D, Malta D, Reis R, Hallal P. Description of the physical activity promotion programs funded by the Brazilian ministry of health. Rev Bras Ativ Fís Saúde. 2013;18(1):63-74. https://doi.org/10.12820/23171634.2013v18n1p63

21. Ribeiro EHC, Garcia LMT, Salvador EP, Costa EF, Andrade DR, Latorre MDRDO, et al. Assessment of the effectiveness of physical activity interventions in the Brazilian Unified Health System. Rev Saude Publica. 2017;51:56. https://doi.org/10.1590/ S1518-8787.2017051006654

22. Ferreira RW, Caputo EL, Häfele CA, Jerônimo JS, Florindo AA, Knuth $A G$, et al. Access to public physical activity programs in Brazil: national health survey, 2013. Cad Saude Publica. 2019;35(2):e00008618. https://doi.org/10.1590/0102$311 \times 00008618$

23. Bagnoli VR, Fonseca AM, Arie WM, Neves EM, Azevedo RS, Sorpreso IC, et al. Metabolic disorder and obesity in 5027 Brazilian postmenopausal women. Gynecol Endocrinol. 2014;30(10):717-20. https://doi.org/10.3109/09513590.20 14.925869

24. Sorpreso IC, Soares Júnior JM, Fonseca AM, Baracat EC. Female aging. Rev Assoc Med Bras (1992). 2015;61(6):553-6. https:// doi.org/10.1590/1806-9282.61.06.553

25. Soares Júnior JM, Lobel A, Ejzenberg D, Serafıni PC, Baracat EC Bariatric surgery in infertile women with morbid obesity: definitive solution? Rev Assoc Med Bras (1992). 2018;64(7):565-7. https:// doi.org/10.1590/1806-9282.64.07.565

26. World Health Organization. Global status report on noncommunicable diseases 2014. Geneva: World Health Organization; 2014. [cited on Dec. 1, 2020]. Available from: http://apps.who.int

27. Bland V, Sharma M. Physical activity interventions in African American women: a systematic review. Health Promot Perspect. 2017;7(2):52-9. https://doi.org/10.15171/hpp.2017.11

28. Borgo MV, Pimentel EB, Baldo MP, Souza JB, Malta DC, Mill JG. Prevalence of cardiovascular risk factors in the population of Vitória according to data from VIGITEL and the National Health Interview Survey of 2013. Rev Bras Epidemiol. 2019;22:e190015. https://doi.org/10.1590/1980-549720190015/iris/bitstream/ handle/10665/148114/9789241564854_eng.pdf;jsessioni$\mathrm{d}=3$ ADF41968363ABF84541D33F309951CB sequence $=1$ 